\title{
STUDY OF VAGINAL INFECTIONS, CERVICAL CYTOLOGY AND PREVALENCE OF MENSTRUAL PROBLEMS IN HIV INFECTED PATIENTS
}

Balvin Kaur Ghai ${ }^{1}$, Alka Patankar ${ }^{2}$, Sarika Thakre ${ }^{3}$

\section{HOW TO CITE THIS ARTICLE:}

Balvin Kaur Ghai, Alka Patankar, Sarika Thakre. "Study of Vaginal Infections, Cervical Cytology and Prevalence of Menstrual Problems in HIV Infected Patients". Journal of Evolution of Medical and Dental Sciences 2015; Vol. 4, Issue 53, July 02; Page: 9202-9210, DOI: 10.14260/jemds/2015/1337

ABSTRACT: OBJECTIVE: To study vaginal infections, cervical cytology and prevalence of menstrual problems in HIV seropositive patients. METHODS: Study Design: hospital based non-randomized prospective observational study. Study Type: case control study. SAMPLE SIZE: 130 cases \& 100 contols. INCLUSION CRITERIA: All married women in the age group of 20-55 yrs. Cases were taken from the seropositive women registered at the ART Centre willing to participate. Controls were HIV seronegative women attending gynaecology OPD. RESULTS: Out of the 130 cases, $78.4 \%$ were on ART \& 21.5\% were not on ART. In the present study, $87.09 \%$ of cases had abnormal Pap smear results compared to $29.09 \%$ of controls. $20 \%$ of cases had SILs compared to $8.18 \%$ of controls. Low grade intraepithelial lesions were 4.56 times more prevalent in cases. In the present study, it was found that $44.4 \%$ of SILs were found in cases with CD4 cell count $<200 / \mu l$. When studied for lower reproductive tract infections, $54.6 \%$ of cases had LRTIs compared to $30 \%$ of controls. The most common infection was candidiasis, found in $20 \%$ cases vs. $10 \%$ controls. CONCLUSION: The present study has shown that the prevalence of Pap smear abnormalities \& LRTIs is higher in HIV seropositive women. Hence, periodic gynaecological testing, Pap smear examination \& vaginal swab testing should be done in HIV seropositive women to provide timely treatment \& early identification of risk factors of malignancy.

KEYWORDS: HIV, SILs, LRTIs, Pap smear, CD4 cell count.

INTRODUCTION: Acquired immunodeficiency syndrome (AIDS) is a global pandemic with cases reported from virtually every country. Worldwide women constitute half of all people living with HIV/AIDS. For women in the reproductive years (15-44 Years), HIV is the leading cause of death and disease worldwide, yet relatively few descriptions of clinical findings associated with HIV in women have been published.

In the presence of HIV infection, particularly the immunodeficiency of AIDS, the clinical presentation, course, complications, and response to conventional therapy of sexually transmitted diseases (STDs), as well as non-infectious gynaecologic disease, may be modified resulting in excessive morbidity.(1-3)

Screening for \& treatment of STDs is considered an integral component of health care for patients infected with HIV, but little information is available to guide the care of female patients. The presence of an STD appears to increase the risk of both acquiring \& transmitting HIV infection. $(4,5)$ Vaginal infections have been seen as a lesser public health priority than cervical infections. Vaginal infections, including Bacterial vaginosis (BV), T. Vaginalis, \& yeast vaginitis (YV), are common among HIV-infected women.(6) BV \& T. Vaginalis have been shown to increase the risk of HIV acquisition among women, underscoring their importance from a public health perspective.(7)

Cervical cancer is the fifth most deadly cancer in women worldwide,(8) despite being a preventable \& curable cancer if detected early. HIV is a well-recognised co-risk factor for carcinoma 


\section{ORIGINAL ARTICLE}

cervix. Here comes the role of Pap smear. A large burden of HIV infection \& increasing HIV epidemic in India threatens to exacerbate incidence of cervical cancer.

The background of conducting this study is due to high prevalence of HIV in Maharashtra (0.5\%). The aim of this study is to compare the prevalence of RTIs, cervical cytological abnormalities \& menstrual problems in HIV-infected women.

AIMS: To study vaginal infections, cervical cytology \& prevalence of menstrual abnormalities in HIV seropositive women.

\section{OBJECTIVES:}

- To compare the occurrence of RTIs among HIV infected \& uninfected women.

- To study \& compare the cytological changes in cervical smear in HIV seropositive with HIV seronegative women.

- To study the prevalence of menstrual problems in HIV-seropositive patients.

- To correlate the results with CD4 counts \& ART status.

MATERIAL \& METHODS: The present study was conducted at the Department of Obstetrics \& Gynaecology, GMC Nagpur from November 2011 till September 2013. It was a non-randomized, prospective, case control, observational study. Present study included a total of 240 patients, 130 cases \& 110 controls.

The approval \& permission of the Ethics Committee of our institute \& National AIDS Control (NACO) Program was obtained. Proper consent of the study population was taken.

\section{Inclusion Criteria:}

1. All married women between the age group of 20-55yrs, attending the outpatient department of Gynaecology, \& ART Centre.

2. HIV status: Cases: HIV seropositive status documented \& registered the ART clinic. Controls: HIV status tested negative at VCTC.

\section{Exclusion Criteria:}

1. Unmarried women.

2. Posthysterectomized women.

\section{METHODOLOGY:}

- Cases \& controls selected after fulfilling the criteria \& obtaining the consent.

- Cases were divided into 2 groups:

Group A: HIV seropositive women on ART.

Group B: HIV seropositive women not on ART.

Thorough history regarding medical, social, menstrual \& treatment history as well as regarding current symptoms taken. Social history included contraceptive use, barrier usage \& addictions. 


\section{ORIGINAL ARTICLE}

- Complete physical examination, including pelvic examination.

- Various specimens \& blood samples:

- Blood for VDRL, haemoglobin estimation, HIV testing \& CD\$ cell count.

- Urine routine \& microscopy.

- Cervical swab from endocervical canal.

- Vaginal swab from posterior fornix.

- Pap smear.

- Viscous swabs were used to collect specimens. Pap smears were collected by cytological brush.

- $\quad$ Statistical software STATA 10.0 was used for statistical analysis.

RESULTS: After thorough analysis of the data, following observations were put forward:

Among the cases, mean age was $34.9 \pm 6.76$ \& that of the controls was $35.40 \pm 9.16$. Mean parity was $1.9 \pm 0.86$ in cases $\& 1.93 \pm 0.82$ in controls with $65 \%$ of patients being multiparous.

\begin{tabular}{|c|c|c|}
\hline Characteristics & No. of Cases $(\mathrm{N}=130)$ & Percentage (\%) \\
\hline \multicolumn{3}{|c|}{ ART } \\
\hline Yes & 102 & 78.4 \\
\hline No & 28 & 21.5 \\
\hline \multicolumn{3}{|c|}{ CD4 Count } \\
\hline$<200$ & 18 & 13.8 \\
\hline $201-500$ & 77 & 59.2 \\
\hline$>500$ & 35 & 26.9 \\
\hline Mean CD4 count & $\begin{array}{c}388.81 \pm 197.21 \\
345(19-971)\end{array}$ & \\
\hline \multicolumn{3}{|c|}{ WHO Stage } \\
\hline I & 26 & 20 \\
\hline II & 53 & 40.7 \\
\hline III & 46 & 35.3 \\
\hline IV & 5 & 3.8 \\
\hline \multicolumn{3}{|c|}{ Symptomatic } \\
\hline Yes & 59 & 45.3 \\
\hline No & 71 & 54.6 \\
\hline
\end{tabular}

Out of the 130 cases, $78.4 \%$ women were on ART \& 21.5\% were not receiving ART. 59.2\% women had CD4 cell counts between $200-500 / \mu$ l, while $13.89 \%$ had counts $<200 / \mu$ l. Majority of patients belonged to WHO stage II \& III, $40.7 \%$ \& $35.3 \%$ respectively. $54.6 \%$ women were asymptomatic compared to $45.3 \%$ symptomatic women.

$54.6 \%$ of cases were asymptomatic compared to $33.6 \%$ of controls. The most common complaint was discharge per vaginum, found in $29 \%$ of controls \& $12.3 \%$ of cases. Menstrual complaints were comparable in cases \& controls with respect to frequency, pattern or duration. 


\section{ORIGINAL ARTICLE}

When correlation between complaints \& ART was studied, it was found that out of the various complaints, menstrual complaints were more common among patients on ART, 9.8\% compared to $0 \%$, indicating that immunosuppression may contribute to the menstrual abnormalities.

\begin{tabular}{|c|c|c|c|c|c|}
\hline & Normal & Abnormal & P-VALUE & ODDS & 95\% C.I. \\
\hline $\begin{array}{c}\text { HIV-Seropositive } \\
\quad(n=124)(\%)\end{array}$ & $16(12.9)$ & 108(87.09) & \multirow{2}{*}{$<0.001$, HS } & \multirow{2}{*}{10.51} & \multirow{2}{*}{$5.27-21.47$} \\
\hline $\begin{array}{c}\text { HIV-Seronegative } \\
(\mathrm{n}=110)(\%)\end{array}$ & $67(60.9)$ & 43(29.09) & & & \\
\hline
\end{tabular}

Out of the 130 cases, 6 had Pap smear results as unsatisfactory, hence were not included in the statistical analysis. Out of the 124 cases, $87.09 \%$ had abnormal Pap smear results compared to $29.09 \%$ of controls $(\mathrm{P}<0.001)$.

\begin{tabular}{|c|c|c|c|c|c|}
\hline $\begin{array}{c}\text { Pap Smear } \\
\text { Report }\end{array}$ & $\begin{array}{c}\text { CASES } \\
\mathbf{n = 1 3 0}(\mathbf{\%})\end{array}$ & $\begin{array}{c}\text { CONTROLS } \\
\mathbf{n = 1 1 0}(\%)\end{array}$ & $\begin{array}{c}\text { ODDS } \\
\text { RATIO }\end{array}$ & $\mathbf{9 5 \%}$ C. I. & P-value \\
\hline Unsatisfactory & $6(4.1)$ & 0 & - & - & $0.022, \mathrm{~S}$ \\
\hline Normal & $16(12.3)$ & $67(61.8)$ & 0.09 & $0.04-0.18$ & $<0.001, \mathrm{HS}$ \\
\hline Atrophic & $6(4.6)$ & $2(1.8)$ & 2.61 & $0.45-26.89$ & $0.229, \mathrm{NS}$ \\
\hline Inflammatory & $76(58.4)$ & $31(28.1)$ & 3.58 & $2.01-6.41$ & $<0.001, \mathrm{HS}$ \\
\hline Bacterial & $33(25.3)$ & $9(8.1)$ & 3.81 & $1.67-9.51$ & $0.005, \mathrm{HS}$ \\
\hline vaginosis & $24(18.4)$ & $13(11.8)$ & 1.68 & $0.77-3.81$ & $0.156, \mathrm{NS}$ \\
\hline Candida & $5(3.8)$ & $4(3.07)$ & 1.06 & $0.22-05.48$ & $0.932, \mathrm{NS}$ \\
\hline Trichomonas & $14(10.7)$ & $5(3.8)$ & 2.53 & $0.82-9.27$ & $0.075, \mathrm{NS}$ \\
\hline Mixed & $26(20)$ & $9(8.18)$ & 2.80 & $1.19-7.12$ & $0.0097, \mathrm{HS}$ \\
\hline SILs & $2(1.5)$ & $2(1.5)$ & 0.84 & $0.06-11.82$ & $1.000, \mathrm{NS}$ \\
\hline ASCUS & $15(11.5)$ & $3(2.7)$ & 4.65 & $1.25-25.62$ & $0.003, \mathrm{HS}$ \\
\hline LSIL & $4(3.07)$ & $3(2.7)$ & 1.13 & $0.18-7.89$ & $1.000, \mathrm{NS}$ \\
\hline HSIL & $4(3.07)$ & $1(0.9)$ & 3.46 & $0.33-17.92$ & $0.379, \mathrm{NS}$ \\
\hline AGUS & $1(0.7)$ & 0 & - & - & $1.000, \mathrm{NS}$ \\
\hline Sqaumous cell Ca & & &
\end{tabular}

Table 3: Distribution of subjects according to Bethesda classification

This table shows the detailed Pap smear results according to Bethesda system of classification, 2001. 58.4\% of cases had inflammatory smear results compared to $28.1 \%$ of controls $(\mathrm{P}<0.001)$. Squamous intraepithelial lesions (SILs) were found in $20 \%$ of cases in comparison to $8.1 \%$ controls $(\mathrm{P}<0.0097)$. Low grade intraepithelial lesion (LSIL) was more common in the cases, $11.5 \%$ vs $2.7 \%$ in controls $(\mathrm{P}<0.003)$. In this study, no association was found between occurrence of Pap smear abnormalities \& ART status. 


\begin{tabular}{|c|c|c|c|}
\hline \multirow{2}{*}{ Pap Smear Result } & \multicolumn{2}{|c|}{ CD4 COUNT } & \multirow{2}{*}{ P-VALUE } \\
\cline { 2 - 3 } & $\begin{array}{c}<\mathbf{2 0 0} \\
\mathbf{n = 1 8} \mathbf{( \% )}\end{array}$ & $\begin{array}{c}\mathbf{> 2 0 0} \\
\mathbf{n = 1 1 2}(\mathbf{\%})\end{array}$ & \\
\hline Unsatisfactory & $1(5.5)$ & $5(4.4)$ & $0.796, \mathrm{NS}$ \\
\hline Normal & $1(5.5)$ & $15(13.3)$ & $0.381, \mathrm{NS}$ \\
\hline Atrophic & 0 & $6(5.3)$ & $0.328, \mathrm{NS}$ \\
\hline Inflammatory & $8(44.4)$ & $68(60.7)$ & $0.194, \mathrm{NS}$ \\
\hline Bacterial vaginosis & $3(16.6)$ & $30(26.7)$ & $0.421, \mathrm{NS}$ \\
\hline Candida & $2(11.1)$ & $22(19.6)$ & $0.437, \mathrm{NS}$ \\
\hline Trichomonas & 0 & $5(4.4)$ & $0.374, \mathrm{NS}$ \\
\hline Mixed & $3(16.6)$ & $11(9.8)$ & $0.334, \mathrm{NS}$ \\
\hline SILs & $8(44.4)$ & $18(16.0)$ & $0.005, \mathrm{~S}$ \\
\hline ASCUS & $2(11.1)$ & 0 & $0.018, \mathrm{~S}$ \\
\hline LSIL & $5(27.7)$ & $10(8.9)$ & $0.020, \mathrm{~S}$ \\
\hline HSIL & $1(5.5)$ & $3(2.6)$ & $0.478, \mathrm{NS}$ \\
\hline AGUS & 0 & $4(3.5)$ & $0.429, \mathrm{NS}$ \\
\hline Sqaumous cell Ca & 0 & $1(0.8)$ & $0.414, \mathrm{NS}$ \\
\hline Table 4: Association of Abnormal Pap smear \\
\hline results with CD4 count in cases \\
\hline \multicolumn{3}{|c}{} \\
\hline
\end{tabular}

This table correlates the Pap smear results with the CD4 cell count, $>200 / \mu \mathrm{l} \&<200 / \mu \mathrm{l} .18$ patients had CD 4 count $<200 / \mu \mathrm{l} \& 112$ patients had count $>200 / \mu \mathrm{l}$. The most significant finding was the occurrence of SILs. $44.4 \%$ patients with CD4 count $<200 / \mu \mathrm{l} \& 16.0 \%$ patients with CD4 count $>200 / \mu \mathrm{l}$ had SILs (P0.005). 27.7\% patients with CD4 count $<200 / \mu \mathrm{l}$ whereas $8.9 \%$ patients with CD4 count $>200 / \mu \mathrm{l}$ had LSIL $(\mathrm{P}<0.020)$. ASCUS was found in $11.1 \%$ of patients with CD4 count $<200 / \mu \mathrm{l}$ compared to no patient with count $>200 / \mu \mathrm{l}(\mathrm{P}<0.018)$.

In our study, no significant correlation was found between Pap smear abnormalities \& WHO stage. Majority of patients with inflammatory results \& SILs belonged to WHO stage II \& III. When studied for the association of complaints with abnormal Pap smear results, it was found that $50.9 \%$ of cases had abnormal Pap smear results but no complaints compared to only $16.2 \%$ of controls.

\begin{tabular}{|c|c|c|c|c|c|}
\hline & Present & Absent & ODDS RATIO & 95\% C.I. & P-VALUE \\
\hline $\begin{array}{c}\text { HIV-seropositive } \\
(\mathrm{n}=130)(\%)\end{array}$ & $71(54.6)$ & $59(45.3)$ & & & \\
\cline { 1 - 3 } $\begin{array}{c}\text { HIV-seroneagtive } \\
(\mathrm{n}=110)(\%)\end{array}$ & $33(30)$ & $77(70)$ & 2.80 & $1.59-4.97$ & $0.0001, \mathrm{HS}$ \\
\multicolumn{5}{|c}{ Table 5: Lower Reproductive Tract Infections } \\
\hline
\end{tabular}

This table shows the distribution of subjects according to the presence of Lower Reproductive Tract Infections (LRTI). The LRTIs were found to be more common among the cases compared to controls, $71(54.6 \%)$ vs $33(30 \%)$ respectively $(\mathrm{P}<0.0001)$. 


\section{ORIGINAL ARTICLE}

\begin{tabular}{|c|c|c|c|c|c|}
\hline LRTI & $\begin{array}{c}\text { CASES } \\
\mathbf{n = 1 3 0}(\mathbf{\%})\end{array}$ & $\begin{array}{c}\text { CONTROLS } \\
\mathbf{n = 1 1 0}(\%)\end{array}$ & $\begin{array}{c}\text { ODDS } \\
\text { RATIO }\end{array}$ & 95\% C. I. & P-Value \\
\hline NPO* & $59(45.3)$ & $66(60)$ & 0.55 & $0.32-0.95$ & 0.024, S \\
\hline BV & $21(16.1)$ & $8(7.2)$ & 2.45 & $0.98=6.68$ & 0.035, S \\
\hline Candidiasis & $26(20)$ & $11(10)$ & 2.25 & $1.00-5.31$ & $0.033, \mathrm{~S}$ \\
\hline Trichomoniasis & $5(3.8)$ & $8(7.2)$ & 0.51 & $0.12-1.83$ & $0.243, \mathrm{NS}$ \\
\hline Pyogenic infection & $17(13.0)$ & $5(4.5)$ & 3.16 & $1.06-11.29$ & $0.022, \mathrm{~S}$ \\
\hline HSV & $2(1.5)$ & $1(0.9)$ & 1.70 & $0.08-10.37$ & $1.00, \mathrm{NS}$ \\
\hline
\end{tabular}

Table 6: Lower genital tract infections in study subjects

(NPO*: No Pathogenic Organism).

Lower reproductive tract infections were found to be more common among the cases. The most common was Candidiasis found in $20 \%$ cases compared to $10 \%$ controls $(\mathrm{P}<0.033) .2^{\text {nd }}$ most common was Bacterial vaginosis, found in $16.1 \%$ cases vs. $7.2 \%$ controls $(\mathrm{P}<0.035)$. The occurrence of LRTIs was found to be independent of ART status. Majority of cases with LRTIs belonged to WHO stage II \&III.

\begin{tabular}{|c|c|c|c|c|c|}
\hline & $\begin{array}{c}\text { BV } \\
\mathbf{n = 2 1 ( \% )}\end{array}$ & $\begin{array}{c}\text { YV } \\
\mathbf{n = 2 6 ( \% )}\end{array}$ & $\begin{array}{c}\text { Trichomoniasis } \\
\mathbf{n = 5 ( \% )}\end{array}$ & $\begin{array}{c}\text { Mixed } \\
\mathbf{n = 1 7 ( \% )}\end{array}$ & $\begin{array}{c}\text { HSV } \\
\mathbf{n = 2 ( \% )}\end{array}$ \\
\hline$<200$ & $3(16.7)$ & $2(7.6)$ & 0 & $4(23.5)$ & $2(100)$ \\
\hline$>200$ & $18(16.0)$ & & $5(100)$ & $13(76.4)$ & 0 \\
\hline P-VALUE & $0.949, \mathrm{NS}$ & $0.310, \mathrm{NS}$ & $0.31, \mathrm{NS}$ & $0.215, \mathrm{NS}$ & $0.018, \mathrm{~S}$ \\
\hline
\end{tabular}

Table 7: Association of LRTIs with CD4 count

When the occurrence of LRTI in HIV-infected women were compared with respect to CD4 count, it was found that majority of infections were found in patients with CD4 count $>200 / \mu$. In majority of studies, Candidiasis was found in HIV- infected patients with CD4 count $<200 / \mu$. But in our study, $92.3 \%$ of patients with Candidiasis had CD4 count $>200 / \mu$ l.

\begin{tabular}{|c|c|c|c|c|c|}
\hline $\begin{array}{c}\text { Menstrual } \\
\text { Complaint }\end{array}$ & $\begin{array}{c}\text { CASES } \\
\mathbf{n = 1 0}(\%)\end{array}$ & $\begin{array}{c}\text { CONTROLS } \\
\mathbf{n = 1 5}(\mathbf{\%})\end{array}$ & $\begin{array}{c}\text { ODDS } \\
\text { RATIO }\end{array}$ & 95\% C. I. & P-Value \\
\hline Ammenorrhoea & $1(10)$ & 0 & - & - & $0.400, \mathrm{NS}$ \\
\hline Oligomenorrhoea & $2(20)$ & 0 & - & - & $0.150, \mathrm{NS}$ \\
\hline Menorrhagia & $7(70)$ & $5(33.3)$ & 1.19 & $0.31-4.92$ & $0.072, \mathrm{NS}$ \\
\hline Dysmenorrhoea & 0 & $6(40)$ & - & - & $0.022, \mathrm{~S}$ \\
\hline Irregular menses & 0 & $4(26.6)$ & - & - & $0.125, \mathrm{NS}$ \\
\hline $\begin{array}{c}\text { Intermenstrual } \\
\text { bleeding }\end{array}$ & 0 & 0 & - & - & - \\
\hline
\end{tabular}

Table 8: Distribution of subjects according to Menstrual irregularities 
Out of the 130 seropositive patients, only 10 patients had menstrual complaints compared to 15 controls. The most common complaint in the cases was menorrhagia. But there was no statistical significance.

DISCUSSION: In the present study, majority(46.2\%) women were in the age group of 31-40yrs which is similar to Greenbalt et al(1999).(9) When comparing the ART status, we found that $78.4 \%$ were on ART compared to $21.5 \%$ not on ART. This was similar to the findings of Prabha Devi et al(2013).(10) In our study, $86.1 \%$ patients had CD4 cell count $>200 / \mu \mathrm{l}$ which was comparable to the study by Vandana Goel et al(2011).(11) Majority of cases in our study belonged to WHO stage II \& III, similar to the findings of Vandana Goel et al(2011).(11)

In our study, $54.6 \%$ of cases had no complaints compared to 33.6 of controls. This was because of the fact that the cases were patients routinely attending the ART clinic whereas the controls were symptomatic seronegative women. The most common complaint was white discharge followed by pain in abdomen. These results were similar to the results of those of B M Jha et al (2012).(12) In our study, $7.6 \%$ of cases had menstrual complaints compared to $12.7 \%$ of controls. Most common complaint was menorrhagia seen in $5.3 \%$ of cases and $4.5 \%$ of controls. Hence, no significant difference was found in the menstrual complaints or the frequency or pattern of menstrual cycle between the cases and controls. Similar findings were reported by Ellerbrock TV et al (1996)(13) and Shah PN et al(1994),(14) suggesting that neither the HIV infection nor the immunusuppression has a clinically relevant effect on menstruation.

Abnormal Pap smear results were found in $87.09 \%$ of cases vs $29.0 \%$ of controls in our study. Similar result was noted by Archana et al (2009)(15) where $64 \%$ of cases had abnormal Pap smear results compared to 31\% of controls. On further analysis of Pap smear results according to Bethesda Classification, we found that inflammatory Pap results were found in $58.4 \%$ of cases compared to 28.1\% of controls, which was comparable to the results Prabha Devi et al(2013)(10) of 74\% inflammatory Pap smears in the cases.

In our study prevalence of SILs was $20 \%$ in the cases compared to $8.18 \%$ in the controls. The risk of SILs in HIV infected cases was nearly double than the controls in study by Joshi et al(2001).(16) Of the various SILs, we found that LSIL was more common in HIV infected cases than the controls, $11.5 \%$ vs $2.7 \%, 3.07 \%$ cases had HSIL compared to $2.7 \%$ of controls. Similar findings were reported by B M Jha et al(2012) ${ }^{(12)}$ with $2.7 \%$ of cases having LSIL compared to $0 \%$ in controls, $3.19 \%$ cases vs $2 \%$ controls having ASCUS, $1.4 \%$ cases having HSIL vs $0.5 \%$ controls. In our study, no statistical significance was found between abnormal Pap smear results \& ART status, similar to the findings of Prabha Devi et al(2013).(10)

The prevalence of SILs was found to be more in cases with CD4 cell count $<200 / \mu$ than in cases with CD4 count $>200 / \mu \mathrm{l}, 44.4 \%$ vs $16.0 \%$ respectively. $11.1 \%$ patients with CD 4 count $<200 / \mu \mathrm{l}$ had ASCUS, while none with CD4 cell count $>200$ had ASCUS. $27.7 \%$ patients with CD4 count $<200 / \mu$ l, and $8.9 \%$ patients with CD4 count $>200 / \mu$ l had LSIL. In a study by La Ruche G et al(1998),(17) it was found that women infected with HIV-1 had increased prevalence of SILs with a decrease in CD4 cell count.

No significant correlation of WHO stages \& ART status with Pap smear abnormalities was found in our study, which is in accordance to findings of the studies by Vandana et al(2011) (11) and B M Jha et $\mathrm{a}(2012) .(12)$

In the present study, the LRTIs were more common in the HIV infected cases than HIV seronegative controls, $54.6 \%$ vs $30 \%$. This was in accordance with the findings of Archana et al 
(2009)(15) of $57 \%$ cases having LRTIs compared to $34 \%$ of controls. $16.1 \%$ of cases had Bacterial vaginosis compared to $7.2 \%$ of controls. $20 \%$ of cases had candidiasis compared to $10 \%$ of controls. Pyogenic infection was also more common in the cases compared to controls, $13.0 \%$ vs $4.5 \%$. Similar results were found in the study by Archana et al(2009)(15) with 34\% of cases having candidiasis compared to $14 \%$ of controls, and mixed/ pyogenic infection found in $10 \%$ of cases compared to $4 \%$ of controls.

No statistically significant association was found of LRTIs with CD4 count, ART status \& WHO stage in cases. This is in accordance with the findings of the study by Vandana et al (2011).(11)

CONCLUSION: From our study, we conclude that optimal screening strategies should be implemented for the frequent and regular gynaecological examination of HIV infected women. The prevalence of Pap smear abnormalities \& LRTIs was found to be higher in HIV infected women. Significant findings were reported in women who were asymptomatic at the time of examination, underscoring the need of routine testing for LRTIs \& early identification of risk factors for malignancy in this group.

\section{BIBLIOGRAPHY:}

1. Minkoff HL, Eisenberger- Matityahu D, Feldman J, Burk R, Clark L. Prevalence and incidence of gynaecologic disaster among women with human immunodeficiency virus. Am J Obstet Gynecol 1999, 180: 824-36.

2. Minkoff HL, Felman L, Holman S, Fazili S, Augenbraun M. Reproductive health hospitalization among women with HIV infections. Am J Obstet Gynecol 1998, 178: 166-70.

3. Frankel RE, Selwyn PA, Mezger J, Andrews S. High prevalence of gynaecologic disease among hospitalized women with human immunodeficiency virus infection. Clin Infectious dis 1997, 25: 706-12.

4. Johnson J, Burnett A, Willett G, et al. High frequency of latent and clinical human papilloma virus cervical infections in immune compromised in human immunodeficiency virus- infected women. Obstet Gynecol 1992, 79: 312-327.

5. Clottey C, Dallabetta G. Sexually transmitted diseases and human immunodeficiency virus: epidemiologic synergy? Infectious dis Clin North Am 1993; 4: 753-70.

6. Moodley P, Connoly C, Sturm AW. Interrelationships among human immunodeficiency virus type 1 infection, bacterial vaginosis, Trichomoniasis, and the presence of Yeasts. J Infect Dis 2002; 185: 69-73.

7. McClelland RS, Lavreys L, katingima C, Overbaugh J, Chohan V, Mandaliya K, et al. Contribution of HIV-1 infection to acquisition of sexually transmitted disease: 10 year prospective study. J Infect Dis 2005; 191: 333-8.

8. Taha TE, Hoover DR, Dallabetta GA, Kumwenda NI, Mtimavalye LA, Yang LP, et al. Bacterial vaginosis and disturbances of vaginal flora: Association with increased acquisition of HIV. AIDS 1998; 12: 1699-706.

9. Greenbelt RM, Bacchetti P, Barkan S, et al. Lower genital tract infections among HIV-infected and high risk uninfected women. Findings of the Women's Interagency HIV study (WIHS). Sex Trans Dis 1999; 26: 143-51.

10. Prabha K D, Narigapalli B P. Conventional Pap smear screening in HIV seropositive women in South India. Indian J Obsteron C, Diomande Met Gynaecol 2013; 63(1): 55-58. 


\section{ORIGINAL ARTICLE}

11. Vandana G, Bhalla P, Sharma A, Mala Y M. Lower genital tract infections in HIV-seropositive women in India. Indian J Sex Trans Dis 2011; 32: 103-7.

12. Jha B M, Patel M, Patel K, Patel J. A study on cervical Pap smear examination in patient living with HIV. Nation J Med Res 2012; 2(1): 81-90.

13. Ellerbrock TV, Wright TC, Bush TJ, Dole P, Brundey K. Characteristics of menstruation in women infected with human immunodeficiency virus. Obstet Gynecol 1996; 87(6): 1030-4.

14. Shah PN, Smith JR, Wells C, Barton BE, Kitchen VS, Steer PJ. Menstrual symptoms in women infected by the human immunodeficiency virus. Obstet Gynecol 1994; 83(3): 397-400.

15. Archana S, Marfatia Y.S, Modi M. Reproductive tract infections in HIV positive women: a case control study. Indian J Sex Trans Dis 2009; 30(1): 16-18.

16. Joshi S, Chandokar A, Krishnan g, Walimbe A, et al. Cervical intraepithelial changes and HIV infection in women attending sexually transmitted disease clinics in Pune. Indian J Med Res. 2011; 113: 161-9.

17. La ruche G, Ramon R, Mensah - Ado I, Bergeron C, Diomande M, et al. Squamous intraepithelial lesions of the cervix, invasive cervical carcinoma, and immune suppresion induced by human immunodeficiency virus in Africa. Dyser-Cl group. Cancer 1998; 82: 2401-8.

\section{AUTHORS:}

1. Balvin Kaur Ghai

2. Alka Patankar

3. Sarika Thakre

\section{PARTICULARS OF CONTRIBUTORS:}

1. Assistant Professor, Department of Obstetrics \& Gynaecology, Government Medical College, Aurangabad.

2. Associate Professor, Department of Obstetrics \& Gynaecology, Government Medical College, Nagpur.

FINANCIAL OR OTHER COMPETING INTERESTS: None
3. Assistant Professor, Department of Obstetrics \& Gynaecology, Indira Gandhi Government Medical College, Nagpur.

\section{NAME ADDRESS EMAIL ID OF THE CORRESPONDING AUTHOR:}

Dr. Balvin Kaur Ghai, Government Medical College, Aurangabad, Maharashtra.

E-mail: richaghai86@gmail.com

Date of Submission: 08/06/2015.

Date of Peer Review: 09/06/2015.

Date of Acceptance: 26/06/2015.

Date of Publishing: 01/07/2015. 